\title{
PHYTOCHEMICAL ANALYSIS OF CALLUS TWO VARIETIES ORTHOSIPHON ARISTATUS (BLUME) MIQ ON MURASHIGE AND SKOOG MEDIA: A STRATEGIC STEP OF SECONDARY METABOLITE PRODUCTION
}

\author{
FAHRAUK FARAMAYUDA ${ }^{1,2}$, TOTIK SRI MARIANI ${ }^{3}$, ELFAHMI ${ }^{1,4}$, SUKRASNO $^{1 *}$
}

1School of Pharmacy, Institut Teknologi Bandung (ITB), Bandung, West Java, Indonesia, 40132, ${ }^{2}$ Faculty of Pharmacy Universitas Jenderal Achmad Yani (UNJANI), Cimahi, West Java, Indonesia, 40532, ${ }^{3}$ School of Life Sciences and Technology, Institut Teknologi Bandung (ITB), Bandung, West Java, Indonesia, 40132, ${ }^{4}$ Biosciences and Biotechnology Research Center, Institut Teknologi Bandung (ITB), Bandung,

West Java, Indonesia, 40132

*Email: sukras@fa.itb.ac.id

Received: 08 Sep 2020, Revised and Accepted: 08 Oct 2020

\section{ABSTRACT}

Objective: The research aimed to provide new information regarding the secondary metabolites content of purple and white-purple Orthosiphon aristatus (Blume) Miq. callus, which can then be used as a basis for developing towards cell suspension and ultimately producing secondary metabolites using bioreactors.

Methods: Callus induction of two varieties of 0 . aristatus were performed by inoculating sterile leaf explants grown on Murashige and Skoog basal media supplemented with 2,4-dichlorophenoxyacetis acid $0.4 \mathrm{ppm}$. The secondary metabolites were analysed and quantified using highperformance liquid chromatography with gradient elution.

Results: The results showed the growth of callus two varieties of 0 . aristatus in growth media MS with 2,4-D 0.4 ppm. Rosmarinic acid content in the acetone extract of the purple variety callus was $1.28 \% \mathrm{w} / \mathrm{w}$, and the white-purple variety was $2.22 \% \mathrm{w} / \mathrm{w}$.

Conclusion: This study could form the basis for the development of rosmarinic acid production by In vitro culture modification.

Keywords: Purple variety 0 . aristatus, White-purple variety 0 . aristatus, Modification of in vitro culture, Growth media, Phytochemical profiling of callus (C) 2021 The Authors. Published by Innovare Academic Sciences Pvt Ltd. This is an open access article under the CC BY license(http://creativecommons.org/licenses/by/4.0/) DOI: http://dx.doi.org/10.22159/ijap.2021.v13s2.14 Journal homepage: https://innovareacademics.in/journals/index.php/ijap

\section{INTRODUCTION}

Orthosiphon aristatus is distributed in China, Africa, Malaysia, India, and Indonesia [1]. Bogor area is one of the areas where cat whiskers are cultivated in Indonesia [2]. The meaning of Orthosiphon is orthos (straight) and siphon (cylinder). [3]. The leaves of 0 . aristatus have a rhombic shape [4]. Based on the color of flowers and petals, there are 0 . aristatus purple, white and white-purple varieties. The secondary metabolite content in purple varieties is higher than in white varieties [5].

The 0 . aristatus by local communities in Indonesia has been used as a diuretic or urinary remedy to cure diabetes mellitus [6]. The plant used alternative medicine in Malaysia and has also been sold as a dietary supplement in recent years [7]. In many European countries, 0 . aristatus is consumed as a herbal tea to promote health due to its high antioxidant properties [8]. Japan uses 0 .aristatus as an essential ingredient in health teas [9-11].

The content of metabolites, the main secondary to 0 . aristatus is sinensetin, rosmarinic acid, and eupatorin. In 2018 Cai reported that sinensetin levels in 0 . aristatus leave, $2.719 \mathrm{mg} / \mathrm{g}$ rosmarinic acid levels in leaves of $19,861 \mathrm{mg} / \mathrm{g}$ and eupatorin levels in leaves 4.731 $\mathrm{mg} / \mathrm{g}$ [12]. The levels of secondary metabolites in 0 . aristatus are still low, so it is necessary to increase the levels, one of which is by plant tissue culture techniques [13].

O. aristatus callus production was obtained when leaf explants were cultured in MS, added with by $1.0 \mathrm{mg} / \mathrm{l} 2,4-\mathrm{D}$, and $1.0 \mathrm{mg} / \mathrm{l}$ NAA as growth regulators. A callus is used to initiate cell suspension culture, $0.75 \mathrm{~g}$ callus cells in the liquid medium MS $20 \mathrm{ml}$ is added with 1.0 $\mathrm{mg} / \mathrm{l} 2,4-\mathrm{D}$ was the best conditions for the culture of 0 . aristatus cell suspension. Optimal cell culture growth is maintained by subculturing every two weeks [14]. Previous research reported that leaf explants of two varieties of 0 . aristatus grown on MS and 2.4-D $0.4 \mathrm{ppm}$ media produced good weight, callus texture within two weeks [15]. Research on the identification and determination of secondary metabolite levels in callus of two varieties of 0 . aristatus has not been reported. The results of this study are expected to provide new information regarding the secondary metabolites content of purple and white-purple 0 . aristatus callus, which can then be used as a basis for developing towards cell suspension and ultimately producing secondary metabolites using bioreactors.

\section{MATERIALS AND METHODS}

\section{Chemicals and reagents}

Media Murashige and Skoogs (MS) was purchased from Phytotechlab (KS, US). 2,4-dichlorophenoxyacetis acid (2,4-D), agar phytagel, rosmarinic acid, and sinensetin were purchased from Sigma (St. Louis, MO, USA). NaOCl Bayclin was purchased from SC Johnson (Jakarta, Indonesia). tween 80 (Labchem). Ethanol, methanol, ethyl acetate, acetone, toluene, acetonitrile HPLC grade, and methanol HPLC grade were purchased from Merck (Jakarta, Indonesia). Formic acid was purchased from Loba Chemie (Mumbai, India).

\section{Instrumentation}

HPLC Gradient (HP-agilent, Germany), autoclave (PBI international Italy), laminar airflow cabinet (Holten, UK), balance sheet (Mettler Toledo, Hong Kong), pH meter (Mettler Toledo, Hong Kong). analytical scales (Shimadzu, Japan), ovens (Memert, Germany), rotary evaporators (Heidolp, Germany).

\section{Material collection and processing}

The parts of the plants used as explants in this study were purple and white-purple varieties of 0 . aristatus, obtained from the Manoko medicinal plant garden, Lembang, Bandung, West Java. The leaves of the $O$. aristatus from the two varieties that have been obtained were carried out wet sorting, then washed with running water. Determination of plants at the School of Life Sciences and Technology, Institut Teknologi Bandung, with letter number 6115/I1. C02.2/PL/2019 shows that the plant specimens examined were purple and white-purple 0 . aristatus. 


\section{Media and equipment sterilization}

The equipments used were glassware and culture bottles washed before use, then wrapped in paper and sterilized using autoclave at a temperature of $121{ }^{\circ} \mathrm{C}$ for $15 \mathrm{~min}$. Other equipment such as tweezers, scalpels, culture knives, sterilized by direct heat from a bunsen fire. The MS media made were sterilized together with the equipments that will be used in the culture process.

\section{Explants sterilization}

The explants of the 0 . aristatus were washed in running water using detergent, soaked in a $2 \%$ fungicide solution for $10 \mathrm{~min}$, cleaned using running water, the explants were put in an erlenmeyer flask, added with $70 \%$ alcohol solution for 1 minute, the remaining alcohol of sterilization was discarded then added to the solution mixture $\mathrm{Na}$ hypochlorite, and Tween 80 were carried out for $5 \mathrm{~min}$. After that, the solution mixture was discarded and the explants rinsed with sterile water three times.

\section{Explants inoculation preparation}

The explants that have been washed were then taken to the culture room. Before starting, make sure the UV lamp on the Laminar Air Flow (LAF) had been turned on for $60 \mathrm{~min}$. Spray the entire surface of the LAF using $70 \%$ alcohol and wipe with a tissue. The equipments culture process and the basic media were sprayed with $70 \%$ alcohol before being transferred to the LAF.

\section{Inoculation of explants on tissue culture media}

The leaf explants of the 0 . aristatus are cut into small square pieces 1 $\mathrm{cm}$ in length and $2 \mathrm{~cm}$ wide in a petri dish and grown on MS medium plus 2,4-D $0.4 \mathrm{ppm}$.

\section{Callus growth observations}

Observations were made by recording every change in explants for three days until a change was seen in the form of explants that turned into a callus. Then the percentage of successful callus growth was calculated. The number of explants that succeeded in forming the callus was divided by the number of explants planted.

\section{Callus drying}

The freshly taken callus was dried in an oven at $50{ }^{\circ} \mathrm{C}$ and weighed every $1 \mathrm{~h}$ until the difference between the first weighing and the next is not more than $0.5 \mathrm{mg}$; this is the dry weight of the sample.

\section{Callus extraction}

The dry callus was then mashed and extracted by maceration using three solvents with different polarities, namely acetone, ethyl acetate, and ethanol. A total of $1 \mathrm{~g}$ of dry callus of two varieties of $O$. aristatus put in a $25 \mathrm{ml}$ vial. Each added solvent is $15 \mathrm{ml}$. Callus that had been soaked in a solvent was let to stand for $24 \mathrm{~h}$ while stirring in an orbital shaker at high speed. The macerate is separated by filtration. The extraction process is repeated at least twice with the same type and amount of solvent. All macerate is collected, then concentrated by evaporating using a rotary evaporator, followed by evaporation of the extract on a water bath until a thick extract was obtained.

\section{Preparation of marker and sample solutions}

Qualitative and quantitative analysis of callus using HPLC has been done by preparation of marker and sample solutions. Rosmarinic acid was weighed as much as $1 \mathrm{mg}$ and dissolved in $1 \mathrm{ml}$ methanol grade HPLC. The stock solution was diluted with methanol to five concentrations ranging from 60 to $100 \mu \mathrm{g} / \mathrm{ml}$. The test solution was prepared by dissolving $15 \mathrm{mg}$ of the extract in $1 \mathrm{ml}$ of methanol and sonicated for $45 \mathrm{~min}$. The test solution is then filtered through a syringe filter.

\section{HPLC instrumentation and conditions}

The HPLC used is a gradient system using a reversed-phase C18 column. Column temperature $25^{\circ} \mathrm{C}$. The mobile phase consisted of $0.1 \%$ formic acid solution and acetonitrile with a gradient elution system where the ratio of formic acid $0.1 \%$ : acetonitrile at $0 \mathrm{~min}$ (85:15), 1 min (85:15), 12 min (35:65), the 15th minute (85:15), the 18th minute (85:15). Flow rate of $1 \mathrm{ml} /$ minute. The separation time was $20 \mathrm{~min}$. The method of determining the levels of secondary metabolites of 0 . aristatus refers to Saidan et al. (2015) with modifications to the maximum wavelength used of $340.6 \mathrm{~nm}$ [16].

\section{Data analysis}

HPLC analysis was prepared in three replications. Callus induction at each concentration of growth regulators was made five repetitions. Data are expressed as mean \pm SD. Data processing was performed by one-way ANOVA, followed by Duncan's multiple range test using SPSS 22 software. $P$ values $<0.05$ were considered statistically significant.

\section{RESULTS AND DISCUSSION}

\section{Plant determination}

The results of the two varieties of 0 . aristatus determination at the School of Life Science and Technology, Bandung Institute of Technology showed that the plant was Orthosiphon aristatus (Blume) Miq. purple flowers and white-purple flowers. Observation of the morphology of the two varieties of 0 . aristatus showed that the leaves of the two varieties had differences in the leaf veins purple varieties have purple leaf veins and white-purple varieties in green. The stems of the purple variety are purple and the stems of the white-purple varieties have a green color. The crown color of the purple variety is purple, while the white-purple variety is white with a purple tinge (fig. 1).

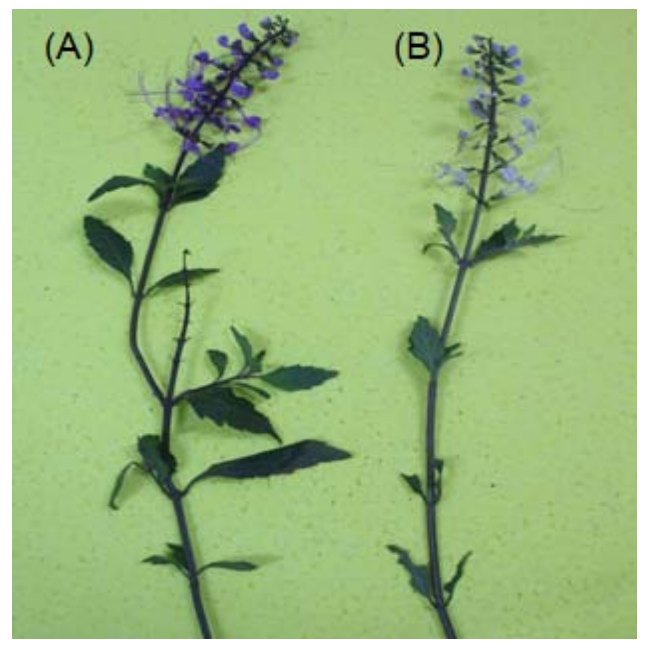

Fig. 1: Observation of the morphology of two varieties of $O$. aristatus. (A) Purple variety; (B) white-purple variety

$O$ aristatus are divided into three varieties white, white-purple and purple. Characterization of $O$. aristatus morphology is important to distinguish the three varieties because according to several previous studies reported that the sinensetin content in purple variety was more significant than white variety [5]. However, there were no reports on the differences in the secondary metabolite content between purple and white-purple varieties. The difference between several varieties of $O$. aristatus can be seen from the morphology of flowers [17]. In this study, the differences in the morphology of flowers from the purple and white-purple varieties, were the purple crown for the purple variety and white purple crown with purple tinge for the white-purple variety. The leaf color for two varieties was green. This study are in line with that reported by Almatar et al. (2013) [18].

\section{Callus growth and drying}

MS medium with the addition of growth regulators 2,4-D $0.4 \mathrm{ppm}$ can grow callus from leaf explants of two varieties of 0 . aristatus within two weeks with $100 \%$ callus response and white-green color. On the 6th day observation, white-purple callus started to grow, and for the purple varieties on the 10th day, the callus started to grow. The dry weight of callus white-purple varieties on day 14 was greater than that of purple varieties (table 1, fig. 2). 
Table 1: Callus induction of two varieties of 0 . aristatus

\begin{tabular}{llllll}
\hline Variety & Growth regulator & $\begin{array}{l}\text { Time formed } \\
\text { callus (days) }\end{array}$ & $\begin{array}{l}\text { Texture } \\
\text { (14 d) }\end{array}$ & $\begin{array}{l}\text { Color } \\
\text { (14 d) }\end{array}$ & $\begin{array}{l}\text { Callus } \\
\text { response (\%) }\end{array}$ \\
\hline Purple variety & MS and 2,4-D 0.4 ppm & $10^{(\mathrm{a})} \pm 0.00$ & friable & White-green & 100 \\
White-purple variety & MS and 2,4-D 0.4 ppm & $6^{(\mathrm{b})} \pm 0.00$ & friable & White-green & 100 \\
\hline
\end{tabular}

The data was given in mean $+\mathrm{SD}, \mathrm{n}=5$. The mean value was significantly different $(\mathrm{p}<0.05)$
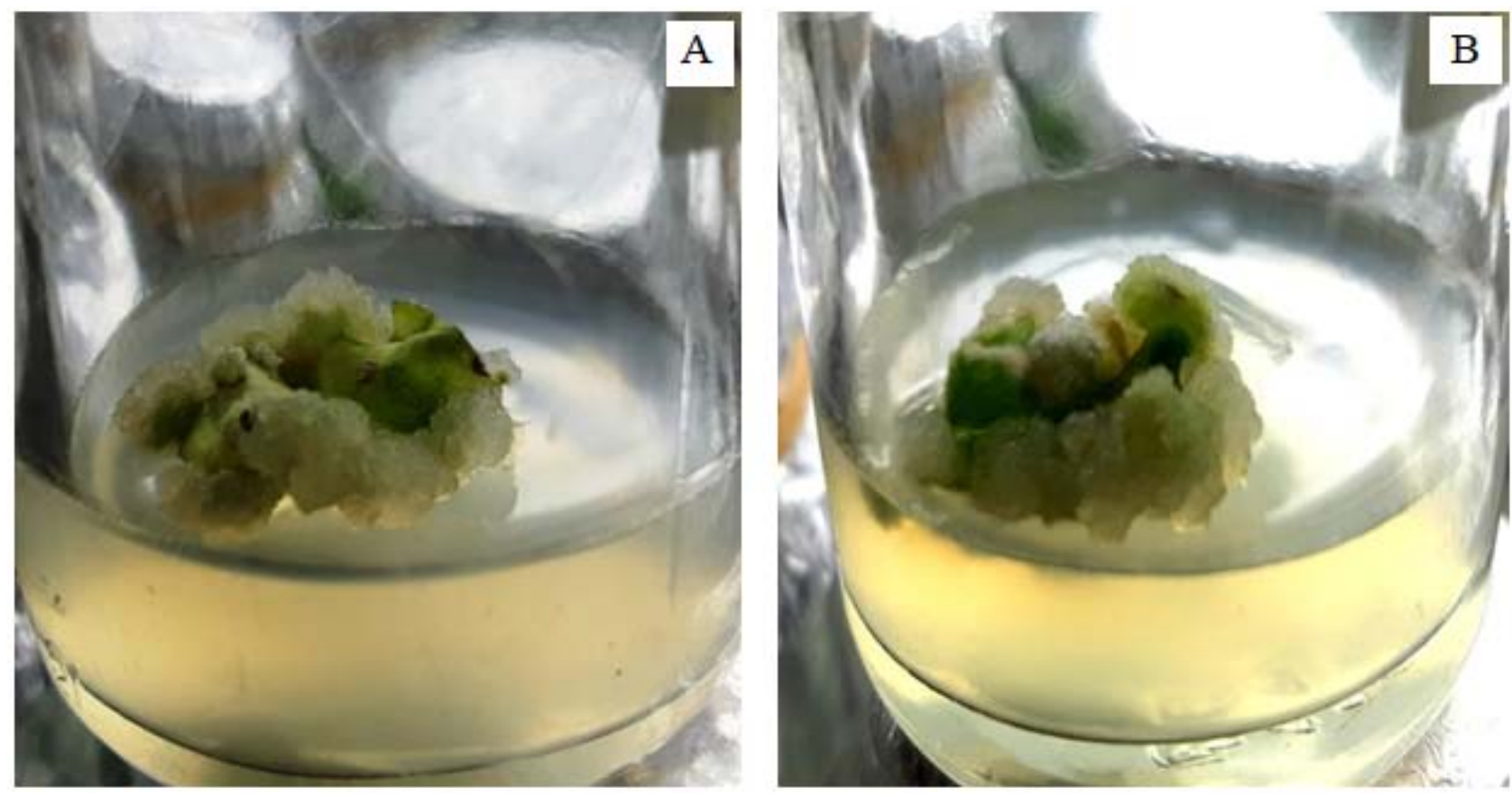

Fig. 2: Callus of two varieties of $O$. aristatus: (A) purple callus with 2,4-D 0.4 ppm; (B) white-purple callus with 2,4-D 0.4 ppm

Callus culture is an In vitro culture technique that is widely used to produce disease-free plant seeds. There are many advantages to the use of callus culture, including it can be produced in large quantities under controlled environmental conditions, does not require a large area of land, and can produce higher metabolites than the original plant. The optimal callus induction depends on the selection and concentration of growth regulators [19-22].

In vitro culture modification that was carried out using a growth regulator 2,4-D $0.4 \mathrm{ppm}$ was able to grow callus from two varieties of $O$. aristatus; there was a statistically significant difference in terms of the time of callus formation in white-purple varieties compared to purple varieties, callus was formed faster in white-purple varieties. The dry weight of callus varieties white-purple was higher than that of purple varieties, but statistically, there was no significant difference. Faramayuda et al. In 2019 reported that the growth regulators 2,4-D $0.4,0.8$, and $1.2 \mathrm{ppm}$ could induce callus growth of two varieties of 0 . aristatus, where 2,4-D $0.4 \mathrm{ppm}$ grew faster and produce callus weights that were higher greater than 2,4-D 0.8 and $1.2 \mathrm{ppm}$ [15]. The results of other studies reported that 0 . aristatus callus was formed on MS medium supplemented with growth regulators NAA 1 ppm+2,4-D 1 ppm [14]. Colored callus was formed on MS medium with the growth regulator Kinetin 1.0 ppm+IAA 1.0 ppm, Kinetin 1.5 ppm+IAA 1.5 ppm, and kinetin 2.0 ppm [23]. $O$. aristatus leaf explants were grown on MS medium, and growth regulator 2,4-D 2 ppm was able to induce the growth of callus. Research on callus induction of two varieties of $O$. aristatus with growth regulators 2,4-D $0.4 \mathrm{ppm}$ has not been reported. The response change in explant size occurs because of the interaction between the explants and the growth environment and growth regulators through nutrient absorption by the explants. The addition of 2,4-D in this study was able to provide a swelling response. In another research report, the addition of 2,4-D $1 \mathrm{ppm}$ to liquid P-4 medium can induce the growth of callus Triticum aestivum L [24] Young leaf explants of Clinacanthus nutans grown on MS medium and 2,4-D $0.50 \mathrm{ppm}$ were able to induce callus with high frequency, and on old leaves, the callus grew well at 2,4-D $0.25 \mathrm{ppm}$ Induction [25]. MS medium supplemented with 2,4-D $0.25 \mathrm{ppm}$ can induce somatic embryos from callus Salicornia brachiata Roxb [26]. Gymnema sylvestre leaf explants grown in MS medium supplemented with 2,4-D 0.50 ppm increased callus growth [27]. 2,4-D $2.50 \mathrm{ppm}$ and $3.00 \mathrm{ppm}$ can form embryogenic callus Saccharum officinarum [28].

\section{Qualitative analysis of callus}

In the qualitative and quantitative analysis of secondary metabolites using HPLC. The marker chromatogram pattern of rosmarinic acid and sinensetin was observed. Rosmarinic acid chromatogram appeared at $6.19 \mathrm{~min}$ and sinensetin at 10.87 min. The standard mixed chromatogram of rosmarinic acid and sinensetin showed the same retention time as the individual chromatogram (fig. 3).

Qualitative analysis of callus in acetone, ethyl acetate, and ethanol extracts of two varieties of $O$. aristatus using HPLC was observed at two wavelengths of $340.6 \mathrm{~nm}$ and $254 \mathrm{~nm}$. Rosmarinic acid was detected in the acetone callus extract of purple and white-purple varieties, but for the sinensetin compound, it was not detected because there were no peaks that appeared at Rt 10.87. In observations at two wavelengths, the peaks that appeared in the acetone callus extract of white-purple varieties were more compared to other extracts (table 2; fig. 4; fig. 5). 


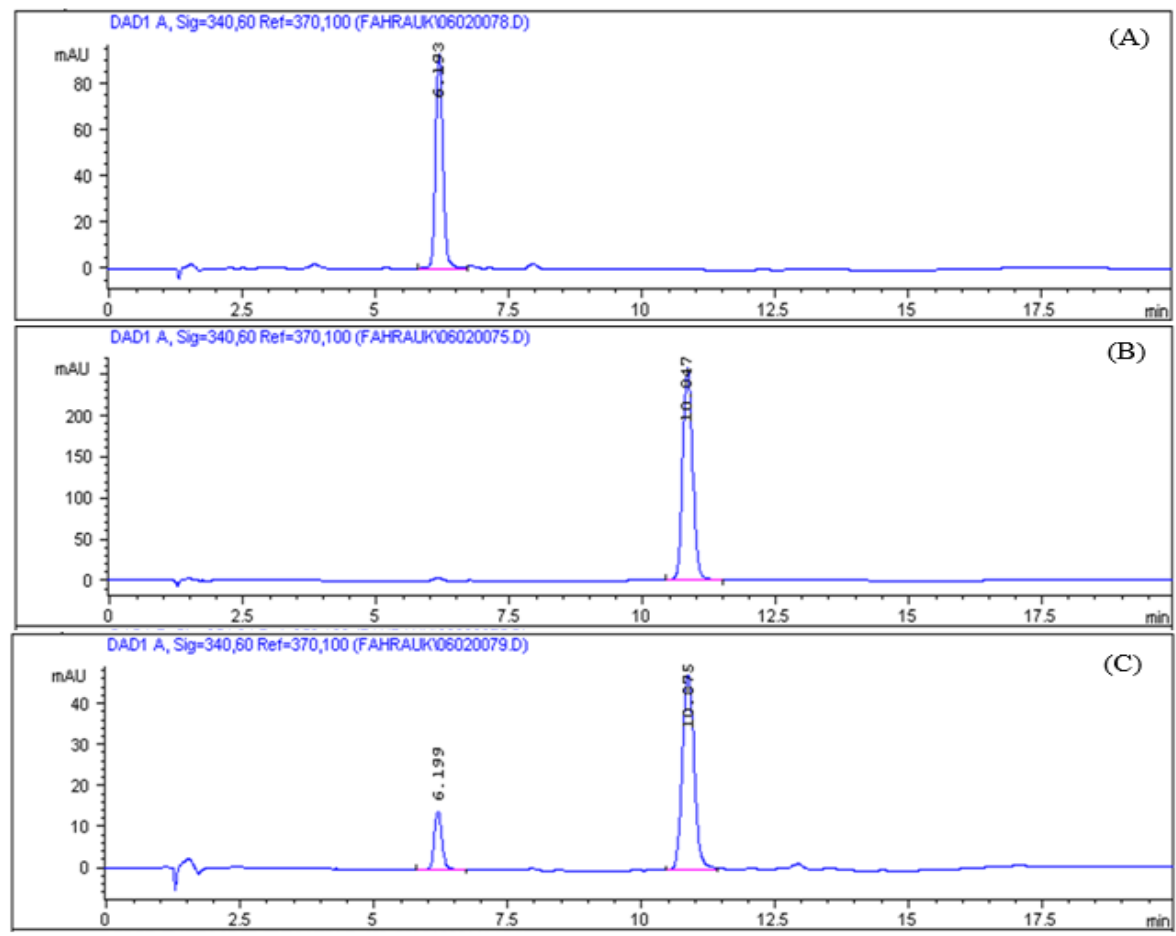

Fig. 3: High performance liquid cromatrography chromatogram of rosmarinic acid and sinensetin markers at $340.60 \mathrm{~nm}$ : (A) rosmarinic acid; (B) sinensetin; (C) marker mixture of rosmarinic acid and sinensetin

Table 2: Data retention time and area of peak callus extract of two varieties of 0 . aristatus

\begin{tabular}{|c|c|c|c|c|}
\hline \multirow[t]{2}{*}{ Sample } & \multicolumn{2}{|c|}{ Signal $340.6 \mathrm{~nm}$} & \multicolumn{2}{|c|}{ Signal $254.24 \mathrm{~nm}$} \\
\hline & RT (min) & Area (mAU*s) & RT (min) & Area (mAU*s) \\
\hline Callus acetone extract & 3.77 & 921.47 & 5.75 & 1796.26 \\
\hline \multirow[t]{3}{*}{ (purple) } & 6.19 & 2609.29 & 7.04 & 459426.67 \\
\hline & 7.08 & 1070.64 & & \\
\hline & 8.85 & 1795.5 & & \\
\hline Callus ethyl acetate extract & 11.06 & 154.95 & 3.42 & 154.95 \\
\hline \multirow[t]{3}{*}{ (purple) } & & & 9.06 & 8720.01 \\
\hline & & & 12.27 & 1668.05 \\
\hline & & & 13.69 & 1937.97 \\
\hline Callus ethanol extract & 6.78 & 1141.62 & 13.79 & 1182.14 \\
\hline (purple) & 12.79 & 1217.32 & & \\
\hline Callus acetone extract & 3.72 & 1525.75 & 5.63 & 5633.04 \\
\hline \multirow[t]{5}{*}{ (white-purple) } & 6.19 & 5123.94 & 7.08 & 362404.00 \\
\hline & 7.13 & 1245.52 & 8.27 & 2509.64 \\
\hline & 8.86 & 4101.92 & 8.88 & 3809.01 \\
\hline & 11.14 & 1660.54 & 12.01 & 1799.15 \\
\hline & & & 13.74 & 2433.08 \\
\hline \multirow[t]{3}{*}{ Callus ethyl acetate extract (white purple) } & 8.85 & 704.40 & 3.45 & 1140.36 \\
\hline & 11.09 & 638.92 & 9.05 & 5704.06 \\
\hline & & & 12.26 & 1324.79 \\
\hline Callus ethanol extract (white-purple) & ND & ND & ND & ND \\
\hline
\end{tabular}

Note: The data were given in mean $(n=3), N D=$ Not Detected

In the qualitative analysis using HPLC at wavelengths of $340.60 \mathrm{~nm}$ and $254.24 \mathrm{~nm}$, several peaks were identified in the extract of acetone, ethyl acetate, and ethanol callus of two varieties of $O$. aristatus. The purple and white-purple varieties of acetone callus $O$. aristatus produced quite a lot of peaks. Both extracts also identified the presence of rosmarinic acid, which was indicated by the appearance of the peak at Rt 6.19. Observations at $254.24 \mathrm{~nm}$ signal on purple variety acetone callus extract showed a peak (Rt 7.02) with a considerable area value of $459426.67 \mathrm{mAU}^{*} \mathrm{~s}$, and on Rt 7.08 callus acetone extract, white-purple varieties also identified peaks with a large area of $362404.00 \mathrm{mAU}{ }^{*} \mathrm{~s}$. The two peaks need to be developed and identified further because they have a large area.

\section{Quantitative analysis of callus}

Quantitative analysis of the callus of two varieties of $O$. aristatus was carried out at the peak observed at the $340.60 \mathrm{~nm}$ signal. In the callus acetone extract of purple and white-purple varieties, rosmarinic acid was detected because the peak appeared with a retention time (RT) of 6.19, where the RT value was the same as the value of rosmarinic acid marker. For the two extracts, rosmarinic acid levels were determined with a linearity range of $60-100 \mathrm{ppm}$, regression equation $y=17.886 x-827.14$ and $R^{2}=0.9954(n=3)$. The rosmarinic acid content in the callus extract of the purple variety was $1.28 \% \mathrm{w} / \mathrm{w}$, and the white-purple variety was $2.22 \% \mathrm{w} / \mathrm{w}$ (table 3). 

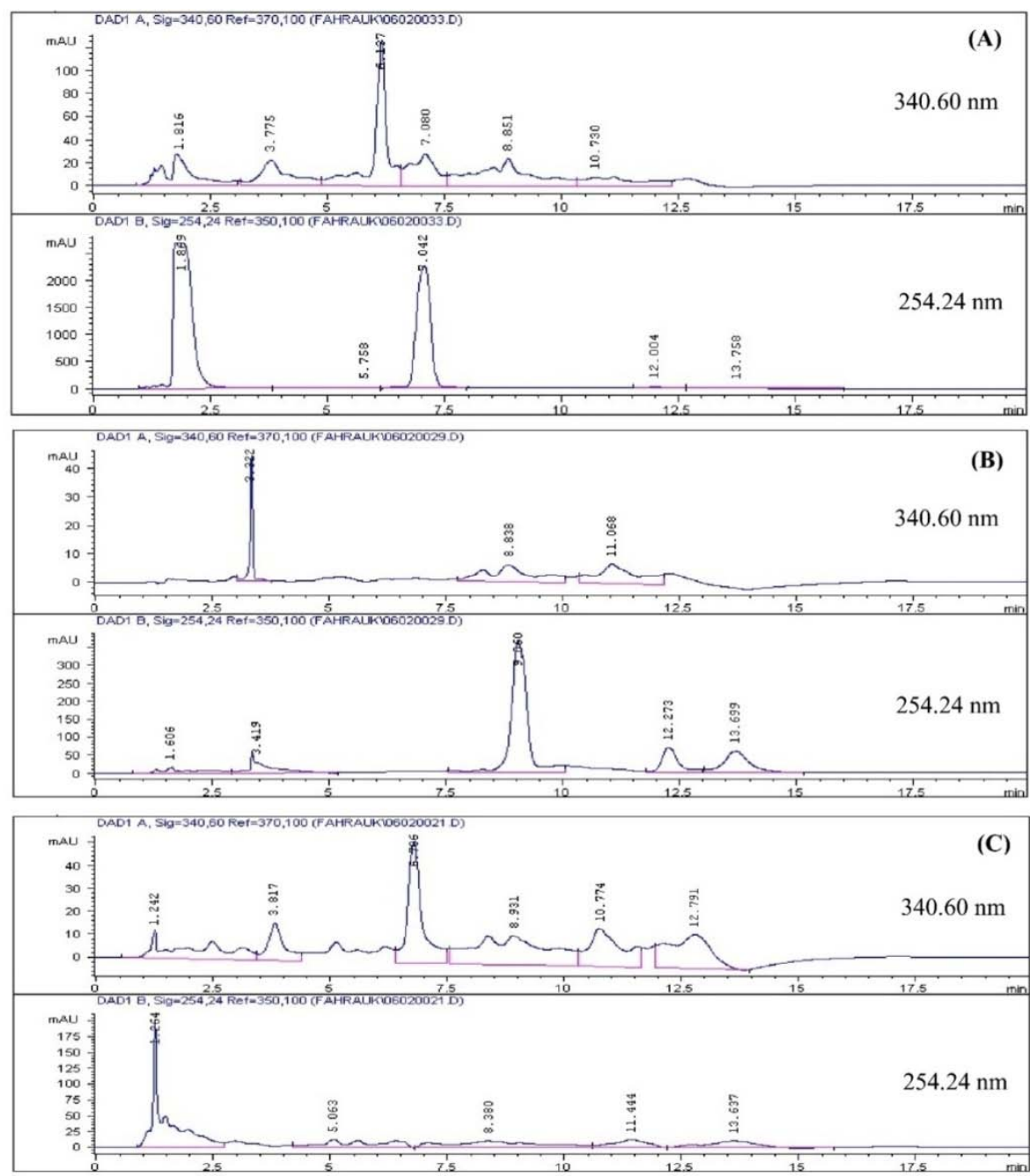

Fig. 4: High-performance liquid chromatography chromatogram extract of the purple variety callus at $340.60 \mathrm{~nm}$ and $254.24 \mathrm{~nm}$. $\mathrm{A}=$ purple variety callus acetone extract, $\mathrm{B}=$ purple variety callus ethyl acetate extract, $\mathrm{C}$ = purple variety callus ethanol extract

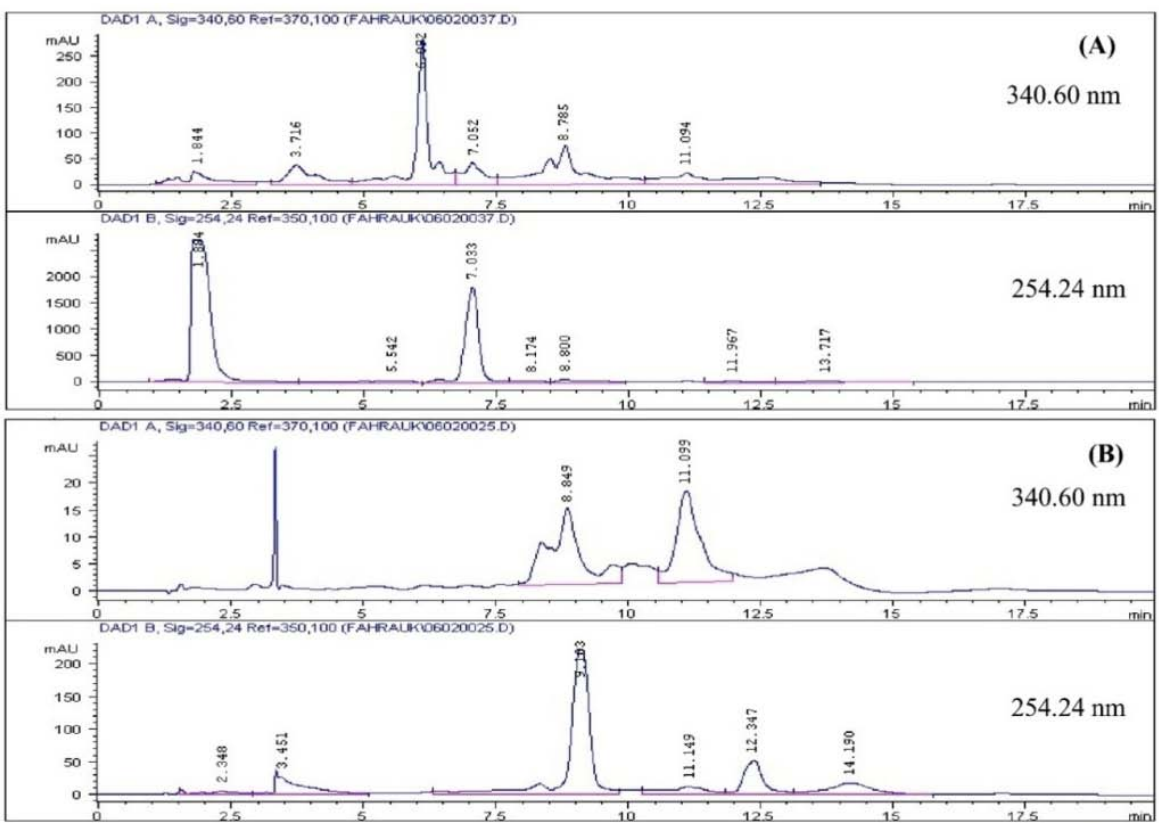

Fig. 5: High-performance liquid chromatography chromatogram extract of the white-purple variety callus at $340.60 \mathrm{~nm}$ and $254.24 \mathrm{~nm}$. A $=$ white-purple variety callus acetone extract and $\mathrm{B}=$ white-purple variety callus ethyl acetate extract 
Table 3: Levels of rosmarinic acid from acetone extracts of two varieties of 0 . aristatus

\begin{tabular}{ll}
\hline Sample & Rosmarinic acid (\% w/w) \\
\hline Purple variety callus acetone extract & $1.28 \pm 0.14^{\mathrm{a}}$ \\
White-purple variety callus acetone extract & $2.22 \pm 0.14^{\mathrm{b}}$ \\
\hline
\end{tabular}

The data were given in mean \pm SD $(n=3)$. The mean value was significantly different $(\mathrm{p}<0.05)$

Quantitative analysis was carried out on rosmarinic acid identified in callus acetone extract using gradient system HPLC following the validated method of Saidan and team in 2015 [16]. The rosmarinic acid content of purple callus acetone extract at a concentration of 15 $\mathrm{mg} / \mathrm{ml}$ was $1.28 \%$, and the white-purple variety was $2.22 \%$. Previous research reports stated that in the original plant, $O$. aristatus that purple varieties had higher secondary metabolite content than white varieties [5]. However, in this study, the rosmarinic acid levels in the callus of white-purple varieties were higher than in purple varieties. This could be due to the effect of In vitro culture modification on the levels of rosmarinic acid, especially in white-purple varieties. Another report stated that the sinensetin content is higher in the purple variety of $O$. aristatus than other varieties [29]. Saidan et al. in 2015 determined the levels of the main secondary metabolites in one variety of 0 . aristatus, and the results were in the ethanol extract $10 \mathrm{mg} / \mathrm{ml}$ sinensetin levels were $1.42 \%$ $\mathrm{w} / \mathrm{w}$, rosmarinic acid $1.61 \% \mathrm{w} / \mathrm{w}$, eupatorin $5.27 \% \mathrm{w} / \mathrm{w}$ and the highest levels of rosmarinic acid was found in methanol: water (1: 1) extract with a value of $4.78 \%$ [16]. Secondary metabolite levels of chloroform fraction of white 0 . aristatus $(1 \mathrm{mg} / \mathrm{ml})$ with HPLC using a non-gradient mobile phase acetonitrile: water (40:60) system were reported by Yam et. al in 2010, where the levels of sinensetin were $2.86 \% \mathrm{w} / \mathrm{w}$, eupatorin $5.05 \% \quad \mathrm{w} / \mathrm{w}$ and 3'-hydroxy$5,6,7,4$ 'tetramethoxyflavone $1.10 \% \mathrm{w} / \mathrm{w}$ [30].

The effort to produce rosmarinic acid from 0 . aristatus cell suspension cultures has been carried out by Bordbar et al. (2015) where cell suspension cultures given the abiotic sucrose elicitor at pH 5.70 can produce rosmarinic acid $25.93 \mathrm{mg} / \mathrm{g}$ dried cell $(2.59 \%$ $\mathrm{w} / \mathrm{w}$ ) [31], the rosmarinic acid content was not much different from the rosmarinic acid levels in the white-purple variety of acetone extract $(2.22 \% \mathrm{w} / \mathrm{w})$. Lim et al. in 2013 reported that the addition elicitor of $45 \mathrm{~g} / \mathrm{l}$ sucrose and $1.5 \mathrm{~g} / \mathrm{l}$ chitosan in liquid proliferation cell medium (MS+1 mg/l 2,4-D and $1 \mathrm{mg} / \mathrm{l} \mathrm{NAA}$ ) could increase total phenolic levels. in cell suspension culture, while the addition of $\mathrm{NaCl}$ elicitor 1-3 g/l, Casein hydrolysate $0.3-3.0 \mathrm{~g} / \mathrm{l}$, and yeast extract 0.25-0.75 g/l did not increase the total phenolic content [32]. The results of this study could be the basis for the production of rosmarinic acid from suspension cultures of 0 . aristatus. The production of rosmarinic acid compounds needs to be increased because these compounds have good pharmacological activities, including antioxidant, anti-inflammatory, antimutagenic, antigenotoxic, cytotoxic, antimetastatic, antiangiogenic, antimicrobe, and immunomodulatory [33]. In silico studies suggest that rosmarinic acid has antidiabetic activity [34]. Rosmarinic acid compound is thought to have activity as an inhibitor of the $\alpha$ glucosidase enzyme activity in Ocimum canum [35].

\section{CONCLUSION}

The extract of acetone callus from two varieties of $O$. aristatus contains rosmarinic acid. The levels of rosmarinic acid in the callus of purple varieties were $1.28 \% \mathrm{w} / \mathrm{w}$, and white-purple varieties were $2.22 \%$ $\mathrm{w} / \mathrm{w}$. The callus of two varieties of 0 . aristatus, which was modified by in vitro culture on MS media with added growth regulator 2,4-D 0.4 ppm, has the potential to be developed in the culture suspension stage for the production of rosmarinic acid compounds.

\section{ACKNOWLEDGMENT}

This research was funded by the Ministry of Research and Technology/National Agency for Research and Innovation through "Penelitian Disertasi Doktor" with contract number 2/E1/KP PTNBH/2020.

\section{FUNDING}

This research was funded by the Ministry of Research and Technology/National Agency for Research and Innovation with contract number 2/E1/KP. PTNBH/2020.

\section{AUTHORS CONTRIBUTIONS}

Fahrauk Faramayuda carried out the experiment and wrote the manuscript with support and supervise from Prof. Sukrasno, Dr. Elfahmi and Dr. Totik Sri Mariani.

\section{CONFLICT OF INTERESTS}

The authors declare no conflict of interest.

\section{REFERENCES}

1. Hossain MA, Mizanur Rahman SM. Isolation and characterisation of flavonoids from the leaves of medicinal plant Orthosiphon stamineus. Arabian J Chem 2015;8:218-21.

2. Febjislami SA., Kurniawati, Melati M, Wahyu Y. Morphological characters, flowering and seed germination of the Indonesian medicinal plant Orthosiphon aristatus. Biodiversitas 2019;20:328-37.

3. Ameer OZ, Salman IM, Asmawi M, Ibraheem ZO, Yam MF Orthosiphon stamineus: traditional uses, phytochemistry, pharmacology, and toxicology. J Med Food 2012;15:678-90.

4. Wiart C. Medicinal plant of Southeast Asia. Bhd, Selangor, Malaysia: Pelanduk Publication Sdn; 2000.

5. Lee W. Micropropagation and cell culture of misai kucing (Orthosiphon stamineus Benth.) and detection of rosmarinic acid in the in vitro cultures, Thesis. Universiti Sains Malaysia; 2004.

6. Mohamed EAH, Siddiqui MJA, Ang LF, Sadikun A, Chan SH, Tan $\mathrm{SC}$, et al. Potent $\alpha$-glucosidase and $\alpha$-amylase inhibitory activities of standardized $50 \%$ ethanolic extracts and sinensetin from Orthosiphon stamineus Benth as anti-diabetic mechanism. BMC Compl Alt Med 2012;12:176.

7. Wiart C. Orthosiphon stamineus, Benth. In: FK Wong. (Ed.). Medicinal plants of Southeast Asia. Selangor: Southeast Asia Prentice Hall; 2002.

8. Indubala JNL. Herbs: The green pharmacy of Malaysia. 1st ed. Kuala Lumpur: Vinpress Sdn. Bhd; 2000.

9. Beaux D, Fleurentin J, Mortier F. Effect of extracts of Orthosiphon stamineus Benth, Hieracium pilosella L., Sambucus nigra L. and Arctostaphylos uva-ursi (L.) Spreng. in rats. Phytother Res 1999;13:222-5.

10. Englert J, Harnischfeger G. Diuretic action of aqueous orthosiphon extract in rats. Planta Med 1992;58:237-8.

11. Masuda T, Masuda K, Nakatani N. Orthosiphol a, a highly oxygenated diterpene from the leaves of Orthosiphon stamineus. Tetrahedron Lett 1992;33:945-6.

12. Cai X, Xiao $\mathrm{C}$, Xue $\mathrm{H}$, Xiong $\mathrm{H}$, Hang $\mathrm{Y}, \mathrm{Xu}$ J, et al. A comparative study of the antioxidants and intestinal protective effects of extracts from different parts of Java tea (Orthosiphon stamineus). Food Sci Nutrit 2018;6:579-84.

13. Hendaryanto DPS, Wijayani A. Tissue culture techniques, introduction, and guidelines for vegetative-modern plant propagation. Yogyakarta: Kanisius; 1994.

14. Wai leng L, Lai Keng C. Establishment of Orthosiphon stamineus cell suspension culture for cell growth. Plant Cell Tissue Org Cult 2004;78:101-6.

15. Faramayuda F, Sukrasno, Elfahmi, Mariani TS. Plant tissue culture in two varieties of Orthosiphon aristatus (Blume) Miq. JOJ Hortic Arboric 2019;2:555597.

16. Saidan NH, Aisha AFA, Hamil MSR, Majid AMSA, Ismail Z. A novel reverse-phase high-performance liquid chromatography method for standardization of Orthosiphon stamineus leaf extracts. Pharmacogn Res 2015;7:23-31.

17. Lai Keng C, Poay Siong L. Morphological similarities and differences between the two varieties of cats whiskers (Orthosiphon stamineus Benth.) grown in Malaysia. Int J Bot 2006;2:1-6. 
18. Almatar MZ, Rahmat, Salleh FM. Premilinary morphological and anatomical study of Orthosiphon stamineus. Indian J Pharm Biol Res 2013;1:1-6.

19. Wójcikowska B, Gaj MD. Expression profiling of auxin response factor genes during somatic embryogenesis induction in arabidopsis. Plant Cell Rep 2017;36:843-58.

20. Nic Can GI, Loyola Vargas VM. The role of the auxins during somatic embryogenesis. In: Somatic embryogenesis: fundamental aspects and applications. Switzerland: Springer Cham; 2016. p. 171-82.

21. Kumar S, Singh R, Kalia S, Sharma SK, Kalia AK. Recent advances in understanding the role of growth regulators in plant growth and development in vitro-I. conventional growth regulators. Indian For 2016;142:459-70.

22. Seldimirova OA, Titova GE, Kruglova NN. A complex morphohistological approach to the in vitro study of morphogenic structures in a wheat anther culture. Biol Bull Russ Acad Sci 2016:43:121-6

23. Ali H, Karsani SA, Othman R, Yaacob JS. Production of colored callus in Orthosiphon stamineus Benth and antioxidant properties of the extracted pigments. Pigments Resin Tech 2018;47:196-207.

24. Zheng M, Konzak C. Effect of 2,4-dichlorophenoxyacetic acid on callus induction and plant regeneration in anther culture of wheat (Triticum aestivum L.). Plant Cell Reports 1999;19:69-73.

25. Phua QY, Chin CK, Asri ZRM, Lam DYA, Subramaniam S, Chew BL. The callugenic effects of 2,4-dichlorophenoxy acetic acid (2,4-d) on leaf explants of sabah snake grass (Clinacanthus nutans). Plant Cell Reports 1999;48:561-6.

26. Rathore MSN, Paliwal KGV, Anand, Agarwal PK. Somatic embryogenesis and in vitro plantlet regeneration in Salicornia brachiata roxb. Plant Cell Tiss Org Cul 2014;120:355-60.
27. Gopi C, Vatsala TM. In vitro studies on the effect of plant growth regulators on callus and suspension culture biomass yield form Gymnema sylvestre R Br. Afr J Biotechnol 2006;5:1215-9.

28. Tahir SM, Victor K, Abdulkadir S. The effect of 2, 4dichlorophenoxy acetic acid (2,4-D) concentration on callus induction in sugarcane (Saccharum officinaru). Nig J Basic Appl Sci 2011;19:213-7.

29. Anggraeni Triantoro. The main content of Orthosiphon aristatus (Blume) Miq. leaves. In: Proceedings of the scientific communication forum. Bogor: Industrial Plant Research and Development Center; 1992.

30. Yam MF, Lim V, Salman IM, Ameer OZ, Ang LF, Rosidah N, et al. HPLC and anti-inflammatory studies of the flavonoid-rich chloroform extract fraction of Orthosiphon stamineus leaves. Molecules 2010;15:4452-66.

31. Bordbar L, Subramaniam S, Jelodar NB, Chan LK. Effects of abiotic factors on cell biomass and rosmarinic acid production in cell suspension cultures of Orthosiphon Stamineus benth. Emirates J Food Agric 2010;27:756-62.

32. Lim LF, Fei M, Zaini M, Chan L. Elicitation of Orthosiphon stamineus cell suspension culture for enhancement of phenolic compounds biosynthesis and antioxidant activity. Ind Crop Prod 2013;50:436-42.

33. Amoah SK, Sandjo LP, Kratz JM, Biavatti MW. Rosmarinic acid-pharmaceutical and clinical aspects. Planta Med 2016;82:388-406.

34. Mehta VA, Sharma P, Kailkhura, Malairaman U. Antioxidant, anti-inflammatory, and antidiabetic activity of hydroalcoholic extract of Ocimum sanctum: an in vitro and in silico study. Asian J Pharm Clin Res 2016;5:44-9.

35. Smita K. Evaluation of $\alpha$-glucosidase inhibitory potential of methanolic leaf extract of ocimum canum. Int J Pharm Pharm Sci 2018;1:126-30. 